\section{M \\ VIA MEDICA www.fr.viamedica.pl}

\title{
The role of T lymphocytes in the pathogenesis of systemic sclerosis and new therapeutic perspectives
}

\section{ABSTRACT}

Systemic sclerosis is a chronic, systemic connective tissue disease, the pathogenesis of which includes, inter alia, abnormalities of the immune system with both innate and adaptive responses. Many scientific studies indicate the key role of T cells in the pathogenesis of the disease. $A$ better understanding of these mechanisms creates the possibility of new therapeutic interventions.

Forum Reumatol. 2018, tom 4, nr 4: 212-218

Key words: Systemic sclerosis; T Iymphocytes; biological treatment
Address for correspondence: dr hab. n. med. Przemysław Kotyla Chair and Clinic of Internal Diseases, Rheumatology and Clinical Immunology, Faculty of Medicine in Katowice, Medical University of Silesia in Katowice ul. Ziołowa 45/47, 40-635 Katowice e-mail: pkotyla@sum.edu.pl

\section{INTRODUCTION}

Systemic sclerosis is a chronic, connective tissue disease of a not fully known aetiology, characterised by excessive and progressive fibrosis of the skin and internal organs, immune disorders (both cellular and humoral responses) and damage to blood vessels manifested as microangiopathy and vasculopathy, which, in turn, leads to tissue ischaemia [1-3].

Recent studies suggest that it is the immune system activation that is a key element in the pathogenesis of the disease. The attention of the researchers is focused on the role of $\mathrm{T}$ cells in the development of key aspects of the disease [4-6].

\section{SHORT CHARACTERISTICS OF T LYMPHOCYTES}

$\mathrm{T}$ lymphocytes are classified in many subpopulations that perform different functions and have a specific surface pattern of differentiation antigens. They all recognise the antigen by the TCR receptor. T lymphocyte differentiation occurs within the thymus. Bone marrow-derived thymocytes precursors penetrate the thymus at the cortex-cord border. These precursors do not have the majority of surface molecules characteristic of $\mathrm{T}$ lymphocytes. They are referred to as double negative (DN) CD4- CD8- thymocytes. In the thymus, immature thymocytes proliferate and undergo differentiation by going through several stages with different patterns of surface antigens. CD4 and CD8 and CD3 proteins are subjected to expression (so-called double positive (DP) thymocytes). As a result of the interaction of these thymocytes with other thymic cells they undergo a positive and negative selection.

The positive selection of CD4+ CD8+ (DP) lymphocytes occurs in the cortical thymus - only those of them that recognise MHC antigens through their TCR receptor pass to the next stage; others die in the apoptosis process.

The next stage of thymocyte maturation is a negative selection, which takes place at the location where the thymus cortex passes into the core. The most important role is played by 
thymic epithelial cells (TECs), containing the AIRE transcription factor (autoimmune regulator), which enables them to express genes responsible for the synthesis and expression of peripheral tissue proteins. As a result, thymocytes come into contact with their own peripheral proteins without leaving the thymus.

As a result of a negative selection, the $\mathrm{T}$ lymphocytes that recognise self antigens are eliminated by apoptosis. The elimination of $\mathrm{T}$ lymphocytes that recognise self antigens - but not present in the thymus - probably occurs in the periphery. At this stage, thymocytes eventually differentiate into cells that have only one of the CD4 or CD8 antigens and migrate to peripheral lymphatic organs. $\mathrm{T}$ lymphocytes that have a CD4 differentiation antigen recognise antigens in the context of MHC class II, while CD8 lymphocytes in the context of MHC class I. The gamma-beta and NKT T-lymphocytes constitute a separate line (Fig. 1).

CD4+ T lymphocyte is the central cell of the immune response. These lymphocytes have an auxiliary/inductive function (Th, $\mathbf{T}$ -helper). They exert their effect on target cells both by the released cytokines and by direct contact. These effector cells include: B lymphocytes, other T cell subpopulations, neutrophils, basophils, eosinophils, monocytes, macrophages. The CD4+ lymphocyte population includes Th1, Th2 and Th17 cells.

An important role in the formation of Th17 cells is played by IL-6 and TGF-beta. Th17 lymphocytes release IL-17, triggering the inflammatory process - activating neutrophils that eliminate the antigen, activating fibroblasts, macrophages for the production of IL-1, IL-6, TNF-alpha, chemokines, or metalloproteinases.

The interaction of Th1 and Th2 lymphocytes plays a significant role in the im- mune response regulation. Th1 lymphocytes mediated by the release of IFN-gamma inhibit the proliferation and function of Th 2 cells. The development of Th1 is initiated by the STAT3 signal transducer and activator transcription and induces the synthesis of the T-bet transcription factor, the main transcription regulator. In turn, the differentiation into Th2 cells is dependent on STAT6 and activated by IL-4. Th2 lymphocyte-produced IL-4, IL-5, IL-10 and IL-13 inhibit the production of cytokines by Th1 and the cellular response mediated by them. The cytokines produced by Th2 stimulate B lymphocytes to produce Ig G2, IgG4 and Ig E antibodies, and Th1 cytokines activate macrophages and induce the synthesis of Ig G1 and Ig G3.

The CD4 cell population, in addition to the Th-lymphocytes, also includes regulatory lymphocytes (Treg) that have a considerable impact on suppressing the immune response and are a key element in maintaining tolerance to self antigens of the host and control of the autoimmune phenomena.

CD8+ cells are cytotoxic lymphocytes (Tc). They have the ability to kill cells by recognising the foreign antigen in the context of MHC class I on their surface. The CD8+ T cell population also includes suppressor lymphocytes (functionally belonging to $\mathrm{T}$ reg) and are also involved in inhibiting the immune response. In the periphery there is also a small subpopulation of the "double negative" lymphocytes (CD4-, CD8-) of an unclear origin and function. On the other hand, gamma beta T-lymphocytes are a heterogeneous population of T lymphocytes. They may be produced in the thymus and peripherally. They perform auxiliary functions in the humoral response, have cytotoxic activity and immunoregulatory properties [7-9] (Fig. 2).

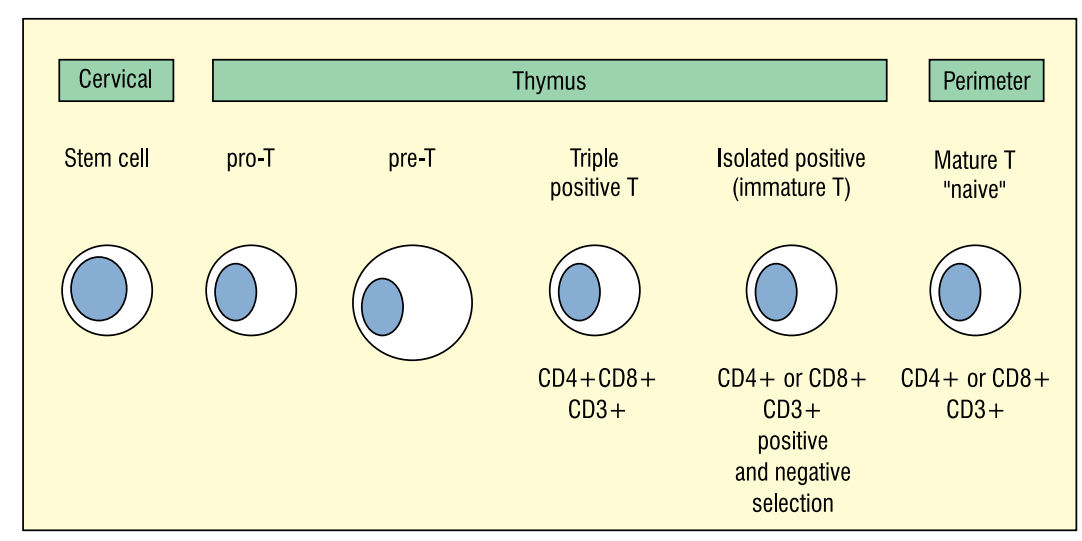

Figure 1. T lymphocytes and their generation in the thymus 


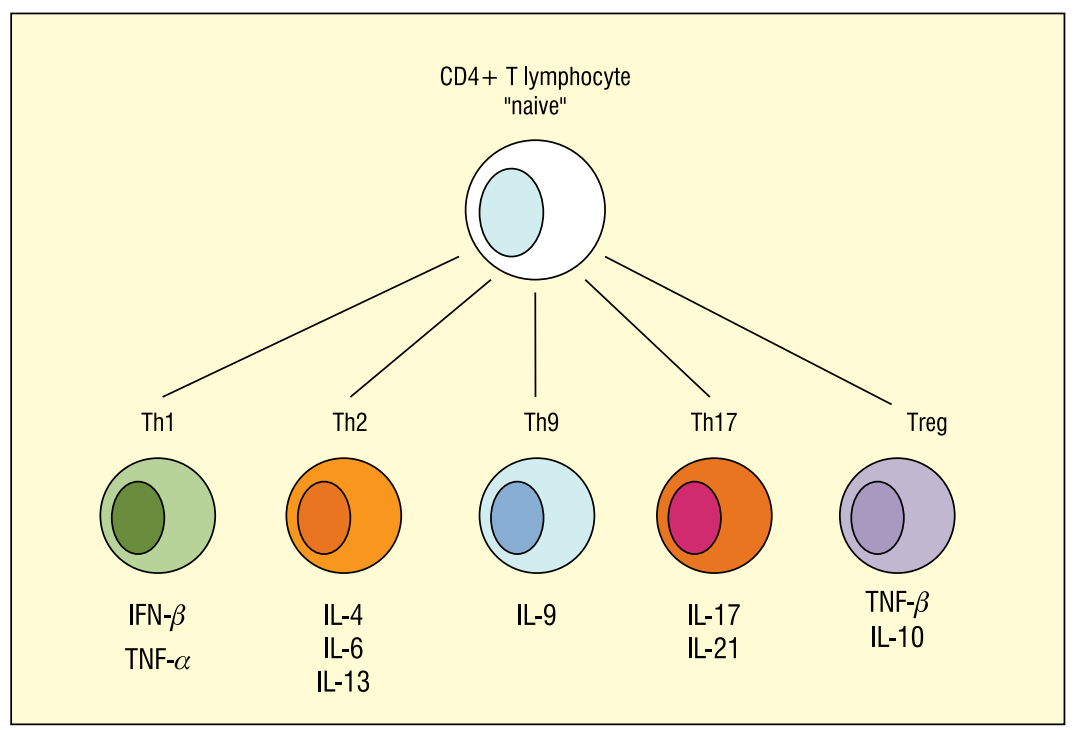

Figure 2. Differentiation of CD4+ T-cells into effector cells secreting specific cytokines (based on [17])

\section{THE ROLE OF T CELLS IN THE PATHOGENESIS OF SYSTEMIC SCLEROSIS}

\section{CELLULAR AND HISTOLOGICAL DISORDERS}

One of the first evidence suggesting that the immune system cells and chronic inflammation are significant in the pathogenesis of the disease was to demonstrate perivascular cell infiltrations (from $\mathrm{T}$ cells - CD4+ dominance, macrophages, mast cells) in the skin sections of patients in the early stages of the disease. Inflammatory infiltrations appear in the skin early, preceding the histological features of fibrosis. Expression of the CD69 molecule, considered to be an early $\mathrm{T}$ cell activation marker, is increased in the skin biopsies of the patients [10]. Some studies also indicate a reduced number of Treg cells in the skin of patients [11]. As the skin fibrosis increases, the activity of the inflammatory process decreases at the cell level [12].

In the pathogenesis of sclerosis, an immune response directed against an unknown antigen is postulated. This is confirmed by the demonstration in skin biopsies of CD4+ T cell proliferation characteristic of the antigen-driven $\mathrm{T}$ -cell response [13]. Following activation, CD4+ $\mathrm{T}$ cells are sensitive to the modifying effects of cytokines and their differentiation into various subpopulations is observed, depending on the cytokine micro-environment. This process makes it possible to adjust the activities of individual cells to the tasks they are assigned to and to use the limited resources of a given lymphocyte population more effectively. Considering (clinical, histopathological and serological) similarities between the systemic sclerosis and the GVH reaction (graft-vs-host), there are many indications that microchimerism $[14,15]$ is a possible mechanism for the formation of this antigen.

\section{PREDOMINANCE OF TH2 RESPONSE (TH2 "POLARISATION") AND THE "SCLERAL" CYTOKINE PROFILE}

\section{IL-4, IL-13}

Th2 cells have been shown to be predominant in systemic sclerosis. These cells are responsible for the rapid repair of tissues after the activation of the destructive factor. The reason for this polarisation is not fully understood. Polarisation of lymphocytes towards Th2 response is observed in the presence of IL-4, and its secretion is initiated probably by the activated monocytes, perhaps the first cell line responsible for the development of the immune response in SSc [16-18].

In patients with SSc, increased concentrations of Th2 stimulation-dependent cytokines (IL-4, IL-5, IL-10, IL-13 and IL-17) are observed in both the skin and serum (mainly Il-4 and Il-6). IL-4 and TGF-beta are the major cytokines that cause fibrosis. IL-4 increases the collagen production by fibroblasts and induces the production of TGF-beta, which stimulates the synthesis of collagen, proteoglycans and fibronectin.

At the same time, it inhibits the activity of metalloproteinases, which favours the accumulation of the extracellular matrix. Additionally, IL-4 induces the synthesis of tenascin, a large extracellular matrix protein [17, 19].

At the same time, increased expression of the CD40 molecule on the surface of fibrobla- 
sts is observed, which is supposed to be responsible for the increased activation of these cells and the increased synthesis of collagen proteins. The increased expression of the CD40 molecule on the surface of fibroblasts is mainly observed in the early stage of the disease ( $<2$ years).

IL-13 is another cytokine produced by Th2 cells. To a large extent, its action coincides with IL-4 (both act through the IL-4-alpha receptor chain). IL-13 has been shown to cause fibrosis directly, in a manner independent of the classical pathway associated with TGF-beta (20). Attention is drawn to the role of this cytokine in the pulmonary fibrosis and the development of interstitial lung disease (ILD) [21]. IL-13 also influences the remodelling of the extracellular matrix by reducing the amount of MMP and simultaneously increasing the activity of the tissue inhibitor of metalloproteinase 1 (TIMP-1) — which leads to an increase in the deposition of the extracellular matrix [17]. Currently, research is underway to identify the factors responsible for the increased deposition of the extracellular matrix, including the role of TGF-beta, but most of all of Th2-dependent cytokines [22, 23].

Recently, a specific CD4+ CD8+ (double-positive) T-cells subtype has been identified in skin of the SSc patients. These cells secrete very large amounts of IL-4 [24]. Their exact significance in the pathogenesis of SSc is not currently known. New data on the role of IL-4 in the pathogenesis of SSc originate from research on CD8 cells. In SSc patients, CD8+ cells secrete large amounts of IL-4 (both in the skin and in the material obtained from BAL), which suggests the contribution of this cytokine in the lung involvement in the disease course [23, 25].

$\mathrm{CD} 8+\mathrm{T}$ cells in SSc patients are characterised by an increased secretion of IL-13, showing a convergence in action compared to IL-4. IL-13 secretion is regulated by the activity of the GATA-3 transcription factor. There are many indications that GATA-3 may be a therapeutic target in SSc in the future, because inhibition of the main transcription factor leads to inhibition of $\mathrm{T}$ cell (naive $\mathrm{T}$ cell) differentiation into Th2 cells and thus inhibits the synthesis of pro-fibrotic mediators as well as the secretion of IL-13 immediately after differentiation into Th2 cells [26].

\section{IL-6}

Interleukin-6 (IL-6) is a classic pro-inflammatory cytokine produced, inter alia, by
T-cells. It performs many functions, including immunoregulatory ones, but also has properties that directly stimulate fibrosis. Serum concentrations of IL-6 are increased in SSc and correlate with the skin thickness [27].

Increased IL-6 concentration levels were also demonstrated in the BAL material and in the immunocytochemistry performed on the skin sections of the patients, mainly in the later stages of the disease, which indicates their role in enhancing the extracellular matrix deposition. IL-6 also intensifies the differentiation of CD4+ T cells into IL-4 secreting cells, which supports fibrosis.

The fact that fibroblasts do not have an IL-6 receptor (they only express the receptor-forming subunit for IL-6-gp 130, they do not directly respond to IL-6. Activation of fibroblasts may, however, take place in a process referred to as trans-signalling (interaction between the soluble receptor for IL-6, IL-6 and gp 130). This process increases the number of cells responsive to IL-6, as the expression of the gp 130 -subunit is widespread [17, 27]. The action of IL- 6 also changes the immune response profile, directing it towards the pro-inflammatory response. For example, in the presence of IL-6, Tregs is converted into Th17-secreting IL-17 cells, which further releases pro-inflammatory and fibrosis-increasing mediators. This passage of Tregs in Th17 under the influence of optimal environmental conditions may explain the reduction of Tregs lymphocytes observed in systemic sclerosis [28-30].

The polarisation towards Th 2 observed in $\mathrm{SSc}$ is responsible for the production of significant amounts of such cytokines as IL-4, IL13, Il-6, participating indirectly or directly in the initiation and propagation of the fibrosis process. When acting together, they may also show synergistic effects (Fig. 3).

\section{REGULATORY LYMPHOCYTES}

In patients with systemic sclerosis, functional and quantitative abnormalities of Treg lymphocytes (Foxp3-positive CD4+ CD25+ T-cells) are also observed. These cells secrete TGF-beta and IL-10 and are essential for maintaining immune tolerance. Depletion of Tregs does not only trigger the phenomena of autoimmunity but also increases the response to foreign antigens.

Some studies have shown an increased amount of Tregs cells in the blood of SSc patients, but a reduced functional capacity to suppress the CD4+ cells. TNF-alpha, the con- 


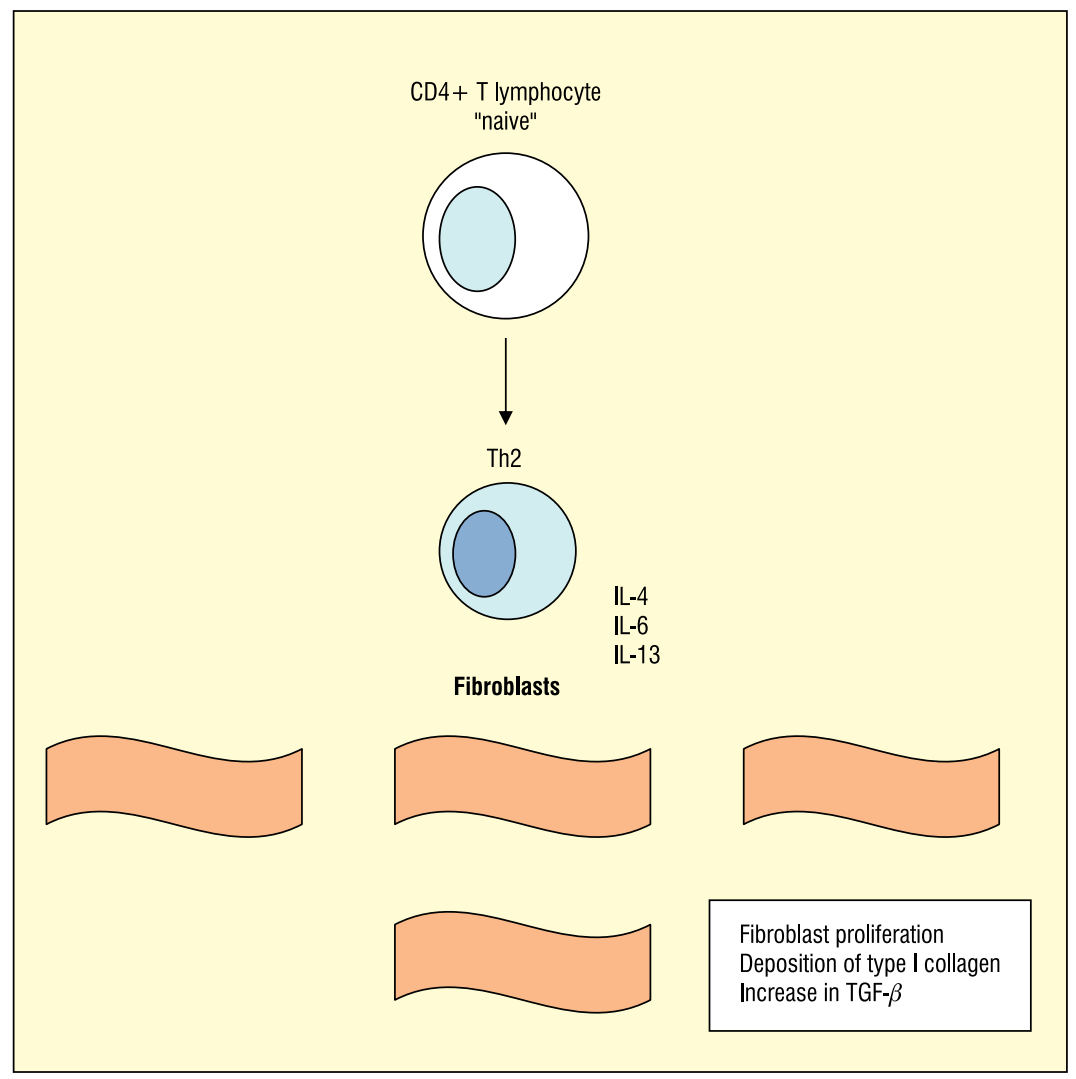

Figure 3. Interaction of cytokines produced by T-cells on fibroblasts

centration of which is increased in systemic sclerosis, has been shown to reduce the suppressive ability of Tregs. Inhibition of TNF-alpha by infliximab restores their suppressive properties [31, 32].

\section{NEW THERAPEUTIC PERSPECTIVES}

Clinical trials are currently being carried out regarding the use of the following drugs in systemic sclerosis:

\section{TOCILIZUMAB (TCZ)}

Considering the significant role of IL-6 in the pathogenesis of fibrosis in SSc, blocking the IL-6 receptor should improve the course of the disease; neutralisation of IL- 6 would also affect the balance between Tregs and Th17. Effectiveness in the treatment of arthritis in the course of SSc has also been demonstrated; phase III RCT trials are currently being conducted

\section{TYROSINE KINASE INHIBITORS (TKIS)}

Recent clinical trials with imatinib (a tyrosine kinase inhibitor) have shown a significant reduction in the number of CD4+ T cells producing IL-4. It is possible that imatinib re- directs the response to the Th1 - dependent one. Analysis of the safety profile from two completed clinical trials highlights important adverse reactions in the form of excessive fluid retention leading to pulmonary oedema in patients with lung disease. Currently, studies are being conducted with low doses of imatinib $(200 \mathrm{mg} / \mathrm{d})$, which exclude patients with an advanced lung disease.

The second generation of tyrosine kinase inhibitors are nilotinib and dasatinib. Among the adverse reactions, cardiac complications (disturbances of conduction) have been observed in the case of nilotinib and the risk of developing PAH (pulmonary arterial hypertension) in the case of dasatinib.

A non-selective inhibitor of receptor tyrosine kinases is nintedanib. At the same time, it inhibits three families of the growth factor receptors involved in angiogenesis and fibrogenesis. They include the platelet-derived growth factor (PDGF, -A, -B, -C, -D; PDGFRa and $\mathrm{b}$ receptors), fibroblast growth factor (FGF, $-1,-2$; FGFR-1 receptors, $2,-3,-4)$ and vascular endothelial growth factor (VEGF, -A, -B, -C, -D, -E; VEGFR-1 receptors, -2, -3) [14]. Nintedanib mainly affects the VEGF (vascular endothelial growth factor) receptor. Ninteda- 
nib was approved in 2014 by the FDA for the treatment of idiopathic pulmonary fibrosis and is currently undergoing a phase II trial for interstitial lung disease in systemic scleroderma (SSc-ILD) [33, 34].

\section{NEW PATHWAYS OF FIBROSIS INHIBITION IN SYSTEMIC SCLEROSIS}

Other potential therapeutic options include inhibition/modulation of the activity of pro-fibrotic cytokines: IL-6 (IL-6 inhibitor) Il 13 (antibodies against Il-13) - further work is underway on inhibitors of intercellular fibrotic signalling, such as: monoclonal anti-bodies CTGF (connective tissue growth factor), endostatin-1-derived peptide, furthermore, NOX4 inhibitors are tested as well as inhibitors of other signalling pathways [35].

An attractive therapeutic target would be inhibition of the GATA-3 factor, which would reduce cell differentiation in the Th2 line and reduce the secretion of IL-13 [36].

\section{LPA-1 INHIBITORS (LIPID \\ LYSOPHOSPHATIDICACID 1)}

LPA-1 is a signal lipid showing pleiotropic effects in mammalian cells. By binding to cell receptors, it affects many pathways associated with the cell growth and survival and its role in cancer development and regeneration processes after tissue damage is considered. Studies in mouse models lacking the receptor for LPA-1 revealed a reduced tendency to develop fibrosis. This mechanism is not fully known. Based on the preclinical evidence, the phase 2 a study has produced encouraging results.

\section{SOLUBLE GUANYLYLA CYCLASE \\ STIMULATORS (SGC)}

Soluble guanylyla cyclase stimulators approved for the treatment of pulmonary arterial hypertension - inhibit the TGF-beta dependent transmission and may suppress fibrosis [33, 37].

\section{THERAPY USING ANTAGOMIRS MOLECULES}

Anti-miRs are a group of chemically modified oligonucleotides that prevent the binding of other molecules to a specific location in the mRNA molecule. They are used to block endogenous microRNA (miRNA) and may be used for therapeutic purposes. Their advantages include possibility of intravenous administration and long duration of action. This technology has been used to affect miRs in animal models of many diseases. The first anti-miR applied clinically is miravirsen - an experimental drug for the treatment of hepatitis C. The use of antagomiR directed against miR21 showed efficacy in pulmonary fibrosis [38].

\section{SUMMARY}

Due to the multi-factorial pathogenesis of the disease, research is conducted on molecules that work in various mechanisms and affect various cellular targets. A better understanding of the immunological mechanisms that are important in the development of this disease will make it possible to develop new therapeutic strategies and to improve the effectiveness of treatment in future. Considering the diversity of clinical images, further exploration of the molecular mechanisms underlying this disease may enable the development of more personalized treatment in future.
1. Kowal-Bielecka 0 , Kuryliszin-Moskal A. Twardzina układowa. Reumatologia. 2012; 50(2): 124-129.

2. Jimenez SA, Derk CT. Following the molecular pathways toward an understanding of the pathogenesis of systemic sclerosis. Ann Intern Med. 2004; 140(1): 37-50, indexed in Pubmed: 14706971

3. Zuber JP, Spertini F. Immunological basis of systemic sclerosis. Rheumatology (Oxford). 2006; 45 Suppl 3: iii23-iii25, doi: 10.1093/rheumatology/kel285, indexed in Pubmed: 16987826.

4. Kalogerou A, Gelou E, Mountantonakis S, et al. Early T cell activation in the skin from patients with systemic sclerosis. Ann Rheum Dis. 2005; 64(8): 1233-1235, doi: 10.1136/ard.2004.027094, indexed in Pubmed: 16014686.

5. Sakkas LI, Chikanza IC, Platsoucas CD. Mechanisms of Disease: the role of immune cells in the pathogenesis of systemic sclerosis. Nat Clin Pract Rheumatol. 2006; 2(12): 679-685, doi: 10.1038/ncprheum0346, indexed in Pubmed: 17133253.

6. Sakkas LI, Platsoucas CD. Is systemic sclerosis an antigen-driven T cell disease? Arthritis Rheum. 2004; 50(6): 1721-1733, doi: 10.1002/art.20315, indexed in Pubmed: 15188347.

7. Gołab J, Kamiński R. Dojrzewanie limfocytów. . In: Gołab J, Jakóbisiak M, Lasek W, Stokłosa T. ed. Immunologia. Wydawnictwo Naukowe PWN, Warszawa 2008: 153-171.

8. Ptak W, Ptak M, Szczepanik M. Limfocyty B i T oraz ich subpopulacje. In: Podstawy immunologii. PZWL, Warszawa 2017.

9. Ptak W, Ptak M, Szczepanik M. Odporność komórkowa mediowana przez limfocyty T CD4+ Th1 i ICD8+ Tc. In: Podstawy immunologii . PZWL, Warszawa 2017.

10. Kalogerou A, Gelou E, Mountantonakis S, et al. Early T cell activation in the skin from patients with systemic sclerosis. Ann Rheum Dis. 2005; 64(8): 1233-1235, 
doi: 10.1136/ard.2004.027094, indexed in Pubmed: 16014686.

11. Klein S, Kretz CC, Ruland V, et al. Reduction of regulatory $T$ cells in skin lesions but not in peripheral blood of patients with systemic scleroderma. Ann Rheum Dis. 2011; 70(8): 1475-1481, doi: 10.1136/ard.2009.116525, indexed in Pubmed: 21097800.

12. Prescott RJ, Freemont AJ, Jones CJ, et al. Sequential dermal microvascular and perivascular changes in the development of scleroderma. J Pathol. 1992; 166(3): 255-263, doi: 10.1002/path.1711660307, indexed in Pubmed: 1517881.

13. Sakkas LI, Xu B, Artlett CM, et al. Oligoclonal T cell expansion in the skin of patients with systemic sclerosis. J Immunol. 2002; 168(7): 3649-3659, indexed in Pubmed: 11907131.

14. Johnson $\mathrm{KL}$, Nelson JL, Furst DE, et al. Fetal cell microchimerism in tissue from multiple sites in women with systemic sclerosis. Arthritis Rheum. 2001; 44(8): 1848-1854, doi: $\quad$ 10.1002/1529-0131(200108)44:8<1848::AID-ART323>3.0.C0;2-L, indexed in Pubmed: 11508438.

15. Szaryńska M. Mikrochimeryzm płodowo- matczyny i jego znaczenie kliniczne. Post Biol Kom. 2007; 34: 85-102.

16. Barron L, Wynn TA. Fibrosis is regulated by Th2 and Th17 responses and by dynamic interactions between fibroblasts and macrophages. Am J Physiol Gastrointest Liver Physiol. 2011; 300(5): G723-G728, doi: 10.1152/ajpgi.00414.2010, indexed in Pubmed: 21292997.

17. O'Reilly S, Hügle T, van Laar JM. T cells in systemic sclerosis: a reappraisal. Rheumatology (Oxford). 2012; 51(9): 1540-1549, doi: 10.1093/rheumatology/kes090, indexed in Pubmed: 22577083.

18. Higashi-Kuwata N, Makino T, Inoue $\mathrm{Y}$, et al. Alternatively activated macrophages (M2 macrophages) in the skin of patient with localized scleroderma. Exp Dermatol. 2009; 18(8): 727-729, doi: 10.1111/j.1600-0625.2008.00828.x, indexed in Pubmed: 19320738.

19. Barsotti S, Bruni C, Orlandi M, et al. One year in review 2017: systemic sclerosis. Clinical and Experimental Rheumatology. 2017.

20. Kaviratne $M$, Hesse $M$, Leusink $M$, et al. IL-13 activates a mechanism of tissue fibrosis that is completely TGF-beta independent. J Immunol. 2004; 173(6): 4020-4029, indexed in Pubmed: 15356151.

21. Zhu Z, Homer RJ, Wang Z, et al. Pulmonary expression of interleukin-13 causes inflammation, mucus hypersecretion, subepithelial fibrosis, physiologic abnormalities, and eotaxin production. J Clin Invest. 1999; 103(6): 779-788, doi: 10.1172/JCI5909, indexed in Pubmed: 10079098.

22. Rankin AL, Mumm JB, Murphy E, et al. IL-33 induces IL-13-dependent cutaneous fibrosis. J Immunol. 2010; 184(3): 1526-1535, doi: 10.4049/jimmunol.0903306, indexed in Pubmed: 20042577.

23. Barsotti S, Stagnaro C, Della Rossa A, et al. Systemic sclerosis: a critical digest of the recent literature. Clin Exp Rheumatol. 2015; 33(Suppl 91): S3-S14.

24. Parel $Y$, Aurrand-Lions $M$, Scheja $A$, et al. Presence of CD4+CD8+ double-positive $T$ cells with very high interleukin-4 production potential in lesional skin of patients with systemic sclerosis. Arthritis Rheum. 2007; 56(10): 3459-3467, doi: 10.1002/art.22927, indexed in Pubmed: 17907151.

25. Atamas SP, Yurovsky V, Wise R, et al. Production of type 2 cytokines by CD8+ lung cells is associated with greater decline in pulmonary function in patients with systemic sclerosis. Arthritis Rheum. 1999; 42(6): 1168-1178, doi: $\quad 10.1002 / 1529-0131(199906) 42: 6<1168:: A I D-A N-$ R13>3.0.C0;2-L, indexed in Pubmed: 10366109.

26. Medsger TA, Ivanco DE, Kardava $L$, et al. GATA-3 up-regulation in CD8 + T cells as a biomarker of immune dysfunction in systemic sclerosis, resulting in excessive interleukin-13 production. Arthritis Rheum. 2011; 63(6): 1738-1747, doi: 10.1002/art.30489, indexed in Pubmed: 21638273.

27. Sato S, Hasegawa M, Takehara K. Serum levels of interleukin-6 and interleukin-10 correlate with total skin thickness score in patients with systemic sclerosis. J Dermatol Sci. 2001; 27(2): 140-146, indexed in Pubmed: 11532378.

28. Krasimirova $E$, Velikova $T$, Ivanova-Todorova $E$, et al. Treg/Th17 cell balance and phytohaemagglutinin activation of T lymphocytes in peripheral blood of systemic sclerosis patients. World J Exp Med. 2017; 7(3): 84-96, doi: 10.5493/wjem.v7.i3.84, indexed in Pubmed: 28890870.

29. Almanzar G, Klein M, Schmalzing M, et al. Disease Manifestation and Inflammatory Activity as Modulators of Th17/Treg Balance and RORC/FoxP3 Methylation in Systemic Sclerosis. Int Arch Allergy Immunol. 2016; 171(2): 141-154, doi: 10.1159/000450949, indexed in Pubmed: 27902985.

30. Truchetet ME, Brembilla NC, Montanari E, et al. Increased frequency of circulating Th22 in addition to Th17 and Th2 lymphocytes in systemic sclerosis: association with interstitial lung disease. Arthritis Res Ther. 2011; 13(5): R166, doi: 10.1186/ar3486, indexed in Pubmed: 21996293.

31. Slobodin G, Ahmad MS, Rosner I, et al. Regulatory T cells (CD4(+)CD25(bright)FoxP3(+)) expansion in systemic sclerosis correlates with disease activity and severity. Cell Immunol. 2010; 261(2): 77-80, doi: 10.1016/j.cellimm.2009.12.009, indexed in Pubmed: 20096404.

32. Radstake TR, van Bon L, Broen J, et al. Increased frequency and compromised function of $T$ regulatory cells in systemic sclerosis (SSc) is related to a diminished CD69 and TGFbeta expression. PLoS One. 2009; 4(6): e5981, doi: 10.1371/journal.pone.0005981, indexed in Pubmed: 19543397.

33. Mendoza FA, Mansoor M, Jimenez SA. Treatment of Rapidly Progressive Systemic Sclerosis: Current and Futures Perspectives. Expert Opin Orphan Drugs. 2016; 4(1): 31-47, doi: 10.1517/21678707.2016.1114454, indexed in Pubmed: 27812432.

34. Inomata M, Nishioka Y, Azuma A. Nintedanib: evidence for its therapeutic potential in idiopathic pulmonary fibrosis. Core Evid. 2015; 10: 89-98, doi: 10.2147/CE.S82905, indexed in Pubmed: 26346347.

35. Asano $Y$. Recent advances in the treatment of skin involvement in systemic sclerosis. Inflamm Regen. 2017; 37: 12, doi: 10.1186/s41232-017-0047-4, indexed in Pubmed: 29259711.

36. Ciechomska M, van Laar J, O'Reilly S. Current frontiers in systemic sclerosis pathogenesis. Exp Dermatol. 2015; 24(6): 401-406, doi: 10.1111/exd.12673, indexed in Pubmed: 25712746.

37. Fukasawa $\mathrm{C}$, Kawaguchi $\mathrm{Y}$, Harigai $\mathrm{M}$, et al. Increased CD40 expression in skin fibroblasts from patients with systemic sclerosis (SSc): role of CD40-CD154 in the phenotype of SSc fibroblasts. Eur J Immunol. 2003; 33(10): 2792-2800, doi: 10.1002/eji.200324088, indexed in Pubmed: 14515263.

38. Baron M. Targeted Therapy in Systemic Sclerosis. Rambam Maimonides Med J. 2016; 7(4), doi: 10.5041/RMMJ.10257, indexed in Pubmed: 27824545. 


\section{Olga Gumkowska-Sroka', Przemysław Kotyla ${ }^{2}$}

${ }^{1}$ Oddział Reumatologii Wojewódzki Szpital Specjalistyczny nr 5 w Sosnowcu,

${ }^{2}$ Katedra i Klinika Chorób Wewnętrznych Reumatologii i Immunologii Klinicznej Wydział Lekarski w Katowicach Śląskiego Uniwersytetu Medycznego w Katowicach

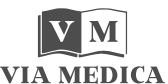

www.fr.viamedica.pl

\section{Rola limfocytów T w patogenezie twarddiny ukiadowej i nowe perspeltywy terapeutyczne}

Artykut jest ttumaczeniem pracy: Gumkowska-Sroka 0., Kotyla P. The role of the lymphocytes in the pathogenesis of systemic sclerosis and new therapeutic perspectives. Forum Reumatol. 2018; tom 4, nr 4: 212-218.

Należy cytować wersję pierwotną.

Piśmiennictwo znajduje się na stronach 217-218

\section{STRESZCZENIE}

Twardzina układowa (systemic sclerosis) jest przewlekłą, układową chorobą tkanki łącznej, w patogenezie której bierze się pod uwagę między innymi zaburzenia funkcjonowania układu immunologicznego z udziałem zarówno odpowiedzi wrodzonej, jak i na- bytej. Wiele badań naukowych wskazuje na kluczową rolę komórek T w patogenezie choroby. Lepsze poznanie tych mechanizmów stwarza możliwość nowych interwencji terapeutycznych.

Forum Reumatol. 2018, tom 4, nr 4: 219-224

Słowa kluczowe: twardzina układowa; limfocyty T; leczenie biologiczne

\section{WSTEPP}

Twardzina układowa (systemic sclerosis) jest przewlekłą, układową chorobą tkanki łącznej o ciągle nie do końca poznanej etiologii, charakteryzującą się nadmiernym i postępującym włóknieniem skóry i narządów wewnętrznych, zaburzeniami immunologicznymi (zarówno odpowiedzi komórkowej, jak i humoralnej) oraz uszkodzeniem naczyń krwionośnych ujawniającym się jako mikroangiopatia i waskulopatia, co w konsekwencji prowadzi do niedokrwienia tkanek [1-3].

Badania ostatnich lat sugerują, że to właśnie aktywacja układu immunologicznego stanowi kluczowy element w patogenezie choroby. Uwaga badaczy skupiła się na roli komórek $\mathrm{T}$ w rozwoju kluczowych aspektów choroby [4-6].

\section{KRÓTKA CHARAKTERYSTYKA LIMFOCYTÓW T}

Limfocyty T dzielą się na wiele subpopulacji, które pełnią różne funkcje i charakteryzują się określonym wzorem powierzchniowych antygenów różnicowania. Wszystkie rozpoznają antygen przez receptor TCR. Miejscem różnicowania limfocytów T jest grasica. Pochodzące ze szpiku prekursory tymocytów wnikają do grasicy na granicy kora-rdzeń. Prekursory te nie posiadają większości charakterystycznych dla limfocytów T cząsteczek powierzchniowych. Określane są jako tymocyty podwójnie negatywne CD4- CD8- (DN, double negati$v e$ ). W grasicy niedojrzałe tymocyty proliferują i ulegają różnicowaniu, przechodząc przez kilka stadiów z różnymi wzorami antygenów powierzchniowych. Ekspresji ulegają białka CD4 i CD8 oraz CD3 (tzw. podwójnie pozytywne tymocyty [DP, double positive]). W efekcie interakcji tych tymocytów z innymi komórkami grasicy przechodzą selekcję pozytywną i negatywną.

Selekcja pozytywna limfocytów CD4+ CD8+ (DP) zachodzi w części korowej grasicy - do dalszego etapu dojrzewania przechodzą jedynie te $\mathrm{z}$ nich, które poprzez swój receptor TCR rozpoznaja antygeny MHC; pozostałe giną w procesie apoptozy.

Kolejnym etapem dojrzewania tymocytów jest selekcja negatywna, która zachodzi
Adres do korespondencji: dr hab. n. med. Przemysław Kotyla Katedra i Klinika Chorób Wewnętrznych i Reumatologii Śląski Uniwersytet Medyczny w Katowicach ul. Ziołowa 45/47, 40-635 Katowice e-mail: pkotyla@sum.edu.pl 


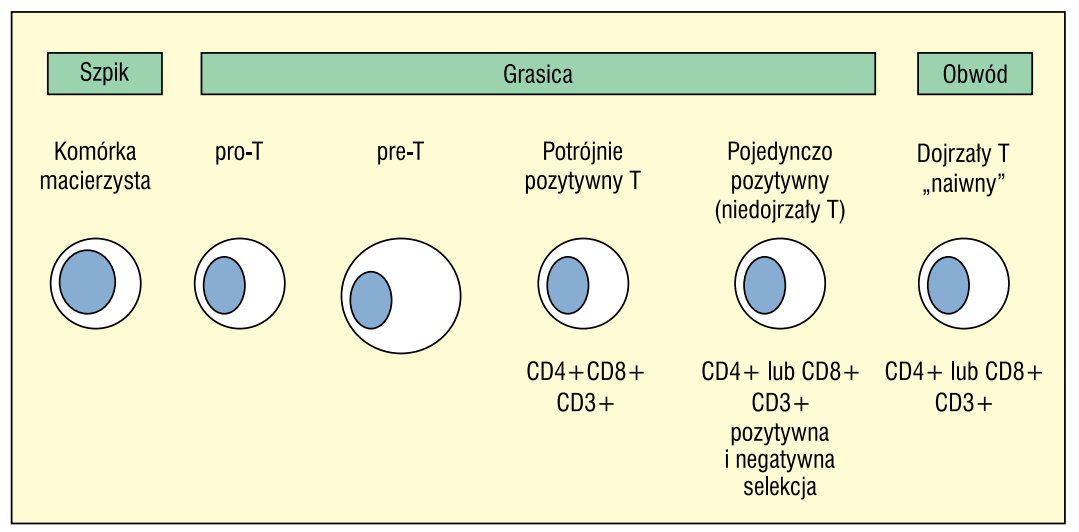

Rycina 1. Limfocyty T i ich generacja w grasicy

w miejscu przejścia kory grasicy w rdzeń. Najważniejszą rolę odgrywają rdzeniowe komórki nabłonkowe (TEC, thymic epithelial cells), zawierające czynnik transkrypcyjny AIRE (autoimmune regulator), który umożliwia im ekspresję genów odpowiedzialnych za syntezę i ekspresję białek tkanek peryferyjnych. Dzięki temu tymocyty stykają się z własnymi białkami obwodowymi bez opuszczania grasicy.

W wyniku selekcji negatywnej eliminowane są przez apoptozę limfocyty $\mathrm{T}$ rozpoznające własne antygeny. Eliminacja limfocytów $\mathrm{T}$ rozpoznających antygeny własne, ale nieobecne w grasicy zachodzi prawdopodobnie na obwodzie. Na tym etapie tymocyty różnicują się ostatecznie w komórki posiadające tylko jeden z antygenów CD4+ albo CD8+ i migrują do obwodowych narządów chłonnych. Limfocyty $\mathrm{T}$ posiadające antygen różnicowania CD4 rozpoznają antygeny w kontekście MHC klasy II, natomiast limfocyty CD8 w kontekście MHC klasy I. Osobną linię stanowią limfocyty $\mathrm{T}$ gamma beta i NKT (ryc. 1).

Limfocyt T CD4+ jest centralną komórką odpowiedzi immunologicznej. Limfocyty te pełnią funkcję pomocniczą/indukcyjną (Th, $\boldsymbol{T}$ -helper). Wywierają swój efekt na komórki docelowe zarówno przez uwalniane cytokiny, jak i na drodze bezpośredniego kontaktu. Tymi komórkami efektorowymi są: limfocyty B, inne subpopulacje limfocytów T, neutrofile, bazofile, eozynofile, monocyty, makrofagi. Populacja limfocytów CD4+ obejmuje komórki: Th1, Th2 oraz Th17.

Istotną rolę $\mathrm{w}$ powstawaniu komórek Th 17 odgrywają Il-6 i TGF-beta. Limfocyty Th17 uwalniają IL-17, wywołując proces zapalny - aktywując neutrofile, które eliminują antygen, aktywując fibroblasty, makrofagi do produkcji IL-1, IL-6, TNF-alfa, chemokin, metaloproteinaz.
Wzajemne oddziaływanie limfocytów Th1 i Th2 odgrywa znaczącą rolę w regulacji odpowiedzi immunologicznej. Limfocyty Th1 za pośrednictwem uwalnianego IFN-gamma hamują proliferację i czynność komórek Th2. Rozwój Th1 jest inicjowany przez szlak sygnałowy STAT3 (signal transducer and activator of transcription) i indukuję syntezę czynnika transkrypcyjnego T-bet, głównego regulatora transkrypcji. $\mathrm{Z}$ kolei różnicowanie w komórki Th2 jest zależne od STAT6 i aktywowane przez IL-4. Wytwarzane przez limfocyty Th2 : IL-4, IL-5, IL-10 i IL-13 hamują produkcję cytokin przez Th1 i odpowiedź komórkową przez nie mediowaną. Cytokiny wytwarzane przez Th2 stymulują limfocyty B do produkcji przeciwciał Ig G2, IgG4 i Ig E, a cytokiny Th1 aktywują makrofagi oraz indukują syntezę Ig G1 i Ig G3.

Do populacji komórek CD4+, poza limfocytami Th, należą również limfocyty regulacyjne (Treg), które odgrywają ważną rolę w hamowaniu odpowiedzi immunologicznej i stanowią podstawowy element utrzymania stanu tolerancji na antygeny własne gospodarza oraz kontroli zjawisk autoimmunologicznych.

Komórki CD8+ są limfocytami cytotoksycznymi (Tc). Mają zdolność zabijania komórek, rozpoznając na ich powierzchni obcy antygen w kontekście MHC klasy I. Do populacji limfocytów T CD8+ należą również limfocyty supresyjne (należące czynnościowo do Treg) i są również zaangażowane w hamowanie odpowiedzi immunologicznej. Na obwodzie istnieje również niewielka subpopulacja limfocytów „podwójnie negatywnych” (CD4- CD8-) o niejasnym pochodzeniu oraz funkcji. Z kolei limfocyty $T$ gamma beta stanowią heterogenną populację limfocytów T. Mogą powstawać w grasicy i obwodowo. Pełnią funkcje po- 


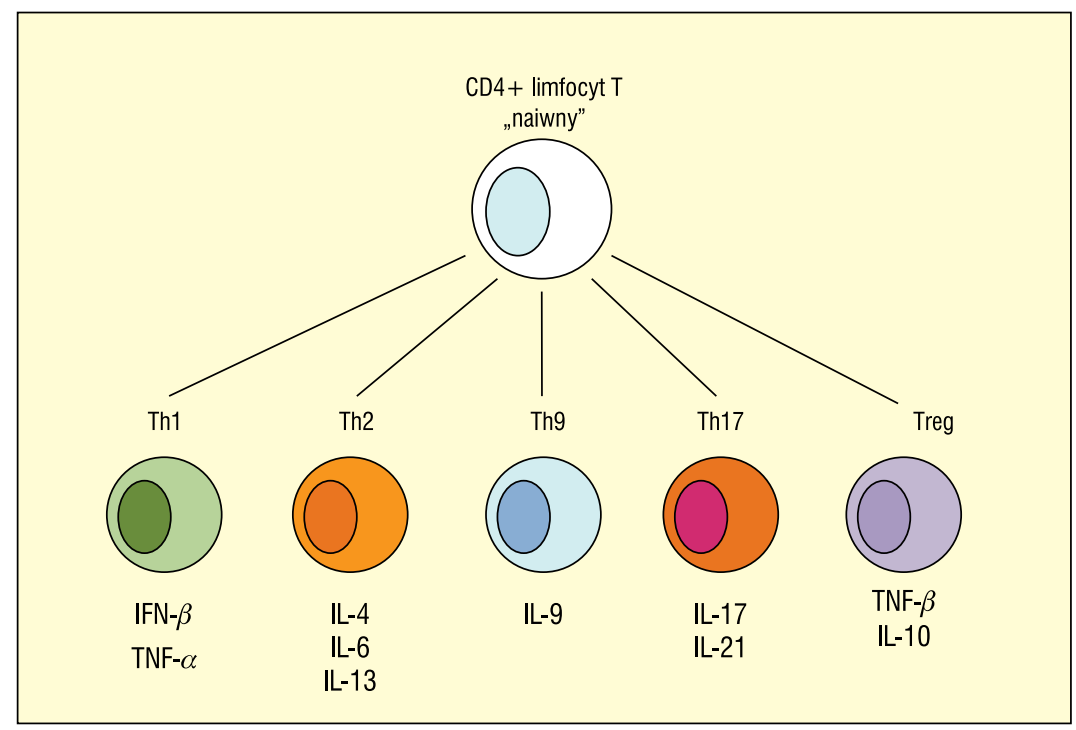

Rycina 2. Różnicowanie komórek T CD 4 + w komórki efektorowe wydzielające specyficzne cytokiny (na podstawie [17])

mocnicze w odpowiedzi humoralnej, wykazują aktywność cytotoksyczną i właściwości immunoregulacyjne [7-9] (ryc. 2).

\section{ROLA KOMÓREK T W PATOGENEZIE TWARDZINY UKLADOWEJ}

\section{ZABURZENIA KOMÓRKOWE I HISTOLOGICZNE}

Jednym z pierwszych dowodów sugerujących, że komórki układu immunologicznego i przewlekłe zapalenie jest istotne w patogenezie choroby, było wykazanie okołonaczyniowych nacieków komórkowych (z komórek T - dominacja CD4+, makrofagów, mastocytów) w wycinkach skóry pacjentów we wczesnej fazie choroby. Nacieki zapalne pojawiają się w skórze wcześnie, przed histologicznymi cechami włóknienia. Ekspresja cząsteczki CD69, uważanej za wczesny marker aktywacji komórki $\mathrm{T}$ jest zwiększona w bioptatach skóry chorych [10]. Niektóre badania wskazują także na zmniejszoną liczbę komórek Treg w skórze chorych [11].W miarę nasilania się włóknienia skóry zmniejsza się aktywność procesu zapalnego na poziomie komórek [12].

W patogenezie twardziny postuluje się wystąpienie odpowiedzi immunologicznej skierowanej przeciwko nieznanemu antygenowi. Potwierdza to wykazanie w bioptatach skóry chorych proliferacji komórek T CD4+ charakterystycznej dla odpowiedzi w zależności od antygenu (antigen-driven T-cell response) [13]. Po aktywacji komórki T CD4+ są wrażliwe na modyfikujące oddziaływanie cytokin i dochodzi do ich różnicowania w różne subpopulacje, w zależności od cytokinowego mikrośrodowi- ska. Proces ten umożliwia dopasowanie czynności poszczególnych komórek do stawianych im zadań i bardziej efektywne wykorzystanie ograniczonych zasobów danej populacji limfocytów. Biorąc pod uwagę podobieństwa (zarówno kliniczne, histopatologiczne, jak i serologiczne) między twardziną układową a reakcją GVH (graft-versus-host, przeszczep przeciw gospodarzowi) wiele wskazuje, że możliwym mechanizmem tworzenia tego antygenu jest zjawisko mikrochimeryzmu $[14,15]$.

\section{PRZEWAGA ODPOWIEDZI TH2 („POLARYZACJA" TH2) I "TWARDZINOWY" PROFIL CYTOKIN}

\section{IL-4, IL-13}

Wykazano, że w twardzinie układowej dominują komórki Th2. Komórki te są odpowiedzialne za szybką naprawę tkanek po zadziałaniu czynnika niszczącego. Przyczyna takiej polaryzacji nie jest do końca poznana. Polaryzacja limfocytów w kierunku odpowiedzi Th2 zachodzi w obecności IL-4, a jej wydzielanie zainicjowane jest prawdopodobnie przez aktywowane monocyty, być może pierwszą linię komórek odpowiedzialną za rozwój odpowiedzi immunologicznej w SSc [16-18].

U chorych na SSc obserwuje się zwiększone stężenia cytokin zależnych od stymulacji Th2 (IL-4, IL-5, IL-10, IL-13 i IL-17) zarówno w skórze, jak i w surowicy (głównie IL-4 i IL-6). Głównymi cytokinami powodującymi włóknienie są IL-4 i TGF-beta. Interleukina 4 nasila produkcję kolagenu przez fibroblasty i indukuje produkcję TGF-beta, 
który stymuluje syntezę kolagenu, proteoglikanów, fibronektyny.

Równocześnie oddziałuje hamująco na aktywność metaloproteinaz przez co sprzyja gromadzeniu się macierzy pozakomórkowej. Ponadto IL-4 indukuje syntezę tenascyny, dużego białka macierzy pozakomórkowej [17, 19].

Równocześnie obserwuje się zwiększoną ekspresję cząsteczki CD40 na powierzchni fibroblastów, co jak się przypuszcza, może odpowiadać za zwiększoną aktywację tych komórek i wzrost syntezy białek kolagenowych. Zwiększoną ekspresję cząsteczki CD40 na powierzchni fibroblastów obserwuje się głównie we wczesnym etapie trwania choroby (<2 lat) [37].

Kolejną cytokiną produkowaną przez komórki Th2 jest IL-13. W dużej mierze jej działanie jest zbieżne z IL-4 (obie działaja przez wspólny łańcuch receptora IL-4-alfa). Wykazano, że IL-13 powoduje włóknienie bezpośrednio, w sposób niezależny od klasycznej drogi związanej z TGF-beta [20]. Zwraca się uwagę na udział tej cytokiny w włóknieniu płuc i rozwoju śródmiąższowej choroby płuc (ILD, interstitial lung disease) [21]. Interleukina 13 wpływa także na remodeling macierzy pozakomórkowej, zmniejszając ilość MMP i równocześnie zwiększając aktywność tkankowego inhibitora metaloproteinazy 1 (TIMP-1), co prowadzi do zwiększenia odkładania macierzy pozakomórkowej [17]. Obecnie trwają badania mające na celu zidentyfikowanie czynników odpowiedzialnych za zwiększoną depozycję macierzy pozakomórkowej, z uwzględnieniem roli TGF-beta, ale przede wszystkim Th2-zależnych cytokin [22, 23].

Ostatnio zidentyfikowano szczególny podtyp komórek T CD4+ CD8+ (double-positive) w skórze pacjentów chorych na SSc. Komórki te wydzielają bardzo duże ilości IL-4 [24]. Ich dokładne znaczenie w patogenezie SSc nie jest obecnie bliżej poznane. Nowe dane dotyczące roli IL-4 w patogenezie SSc pochodzą z badań nad komórkami CD8. U chorych na SSc również komórki CD8+wydzielają duże ilości IL-4 (zarówno w skórze, jak i w materiale uzyskanym z BAL), co sugeruje udział tej cytokiny w zajęciu płuc w przebiegu choroby [23, 25].

Komórki T CD8+ u chorych na SSc charakteryzuje wzmożona sekrecja IL-13, wykazująca zbieżny profil działania w porównaniu z IL-4. Wydzielanie IL-13 jest regulowane aktywnością czynnika transkrypcyjnego GATA-3. Wiele wskazuje, że GATA-3 może być w przyszłości celem terapeutycznym w SSc, ponieważ inhibicja głównego czynnika trans- krypcyjnego doprowadza do zahamowania różnicowania komórek $\mathrm{T}$ (naive $T$ cell) w komórki Th2 i w ten sposób powoduje zahamowanie syntezy mediatorów promujących włóknienie, jak również sekrecji IL-13 bezpośrednio po zróżnicowaniu w komórki Th2 [26].

\section{IL-6}

Interleukina 6 (IL-6) jest klasyczną prozapalną cytokiną produkowaną między innymi przez komórki T. Spełnia wiele funkcji, między innymi immunoregulacyjne, ale także ma właściwości bezpośrednio pobudzające włóknienie. Surowicze stężenia IL-6 są zwiększone w SSc i korelują z grubością skóry [27].

Zwiększone stężenia IL-6 wykazano także w materiale uzyskanym z BAL oraz w badaniach immunocytochemicznych w wycinkach skóry chorych, głównie w późniejszych stadiach choroby, co wskazuje na jej rolę w nasilaniu depozycji macierzy pozakomórkowej. Interleukina 6 nasila także różnicowanie komórek T CD4+ w komórki wydzielające IL-4, co podtrzymuje włóknienie.

Ponieważ fibroblasty nie mają receptora dla IL-6 (wykazują wyłącznie ekspresję podjednostki budującej receptor dla IL-6-gp 130) nie odpowiadają bezpośrednio na IL-6. Aktywacja fibroblastów może zachodzić jednak w procesie określanym jako trans-signalling (współdziałanie pomiędzy rozpuszczalnym receptorem dla IL-6, IL-6 i gp 130). Proces ten zwiększa liczbę komórek odpowiadających na IL-6, jako że ekspresja podjednostki gp 130 jest szeroko rozprzestrzeniona $[17,27]$. Działanie IL-6 zmienia również profil odpowiedzi immunologicznej, kierując ją typowo w stronę odpowiedzi prozapalnej. Dla przykładu, w obecności IL-6 dochodzi do konwersji Tregs w komórki Th17 — wydzielające IL-17, co powoduje dalsze uwalnianie prozapalnych oraz nasilających włóknienie mediatorów. To przejście Tregs w Th17 pod wpływem optymalnych warunków środowiska może tłumaczyć obserwowaną w twardzinie układowej redukcję limfocytów Tregs [28, 29, 30].

Obserwowana w SSc polaryzacja w kierunku odpowiedzi Th2 odpowiada za produkcję znacznej liczby takich cytokin, jak IL-4, IL-13, IL-6, uczestniczących pośrednio lub bezpośrednio $\mathrm{w}$ inicjowaniu i propagacji procesu włóknienia. Działając wspólnie mogą wykazywać także działanie synergistyczne (ryc 3).

\section{LIMFOCYTY REGULATOROWE}

U chorych na twardzinę układową obserwuje się również zaburzenia funkcjonalne i ilo- 


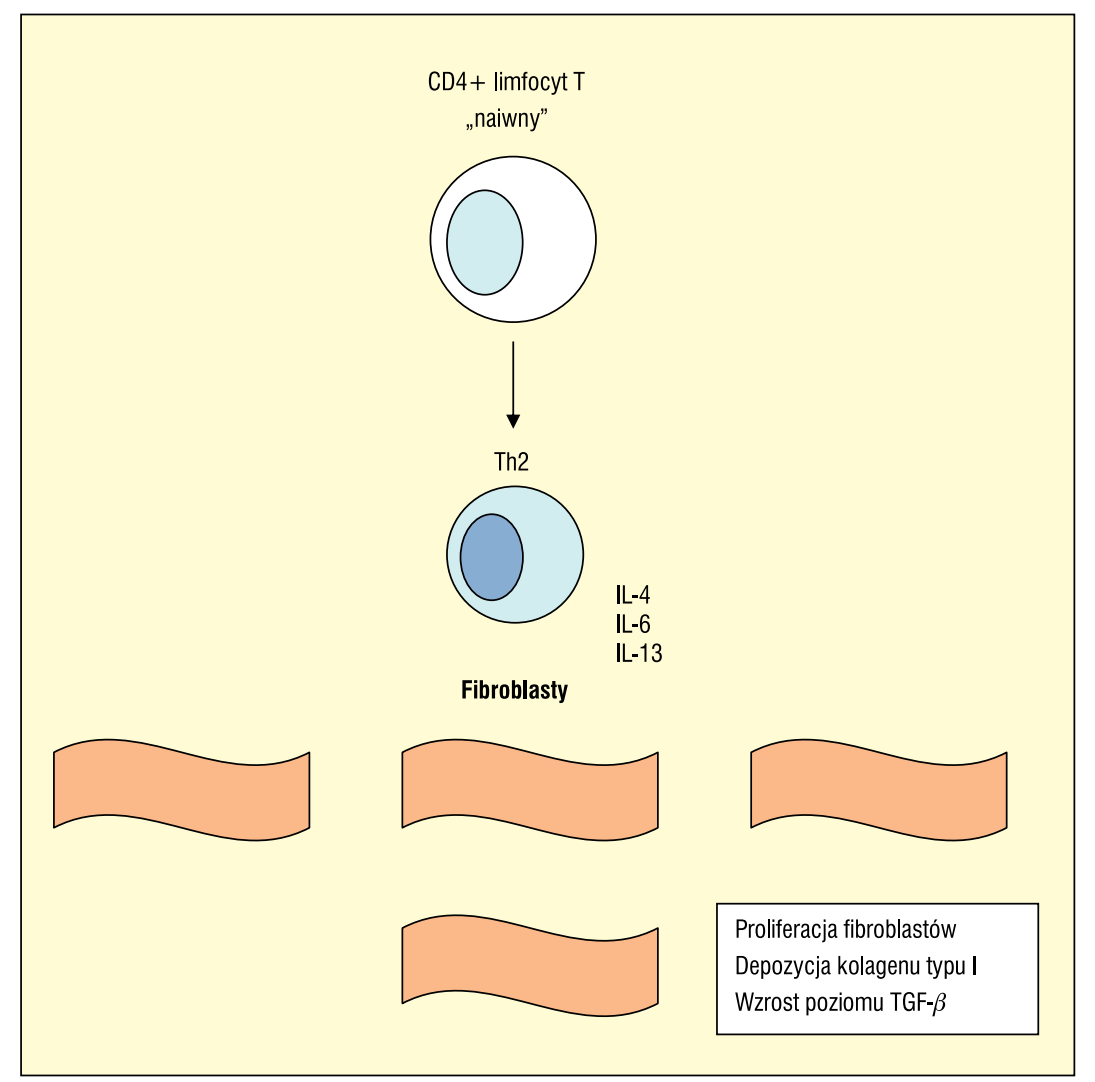

Rycina 3. Oddziaływanie cytokin produkowanych przez komórki T na fibroblasty

ściowe limfocytów Treg (Foxp3-positive CD4+ CD25+ T-cells). Komórki te wydzielają TGF-beta oraz IL-10 i są niezbędne w utrzymaniu tolerancji immunologicznej. Deplecja Tregs nie tylko wyzwala zjawiska autoimmunizacji, ale także nasila odpowiedź na antygeny obce.

W niektórych badaniach wykazano zwiększoną liczbę komórek Tregs we krwi pacjentów z SSc, ale zmniejszoną funkcjonalną zdolność do supresji komórek CD4+. Wykazano, że TNFalfa, którego stężenie jest w twardzinie układowej zwiększone, zmniejsza supresyjną zdolność Tregs. Inhibicja TNF-alfa przez infliximab przywraca ich supresyjne właściwości [31, 32].

\section{NOWE PERSPEKTYWY TERAPEUTYCZNE}

Obecnie trwają badania kliniczne nad zastosowaniem w twardzinie układowej wyszczególnionych poniżej leków.

\section{TOCILIZUMAB (TCZ)}

Biorąc pod uwagę istotną rolę IL-6 w patogenezie włóknienia w SSc blokada receptora dla IL-6 powinna poprawić przebieg choroby; neutralizacja IL-6 wpłynęłaby również na równowagę pomiędzy Tregs a Th17. Wykazano także skuteczność w leczeniu zapalenia stawów w przebiegu SSc; obecnie prowadzone są badania III fazy (phase III RCT)

\section{INHIBITORY KINAZY TYROZYNOWEJ (TKIS)}

W ostatnim badaniu klinicznym z użyciem imatinibu (inhibitora kinazy tyrozynowej), wykazano znaczącą redukcję w liczbie komórek T CD4+ produkujących IL-4. Jest możliwe, że imatinib przekierowuje odpowiedź na Th1-zależną. W analizie profilu bezpieczeństwa z dwóch ukończonych badań klinicznych podkreślono istotne działania niepożądane w postaci nadmiernej retencji płynów prowadzącą w przypadku pacjentów $\mathrm{z}$ chorobą płuc do obrzęku płuc. Obecnie prowadzone są badania z małymi dawkami imatinibu (200 mg/d.) oraz $\mathrm{z}$ wykluczeniem pacjentów $\mathrm{z}$ zaawansowaną chorobą płuc.

Druga generacja inhibitorów kinazy tyrozynowej to nilotinib i dasatinib. Wśród działań niepożądanych obserwowano powikłania kardiologiczne (zaburzenia przewodzenia) w przypadku nilotinibu oraz ryzyko rozwoju tętniczego nadciśnienia płucnego (PAH, pulmonary artrial hypertension) w przypadku dasatinibu.

Nieselektywnym inhibitorem receptorowych kinaz tyrozynowych jest nintedanib. 
Hamuje jednoczasowo trzy rodziny receptorów dla czynników wzrostu, biorących udział w angiogenezie i fibrogenezie. Są to płytkopochodny czynnik wzrostu (PDGF, platelet derived growth factor $-A,-B,-C,-D$; receptory PDGFRa i b), fibroblastyczny czynnik wzrostu (FGF, fibroblast growth factor -1, -2; receptory FGFR-1, -2, -3, -4) i naczyniowo-śródbłonkowy czynnik wzrostu (VEGF, vascular endothelial growth factor $-A,-B,-C,-D,-E$; receptory VEGFR-1, -2, -3) [14]. Nintedanib oddziałuje głównie na receptor dla VEGF(vascular endothelial growth factor). Nintedanib został w 2014 roku zaaprobowany przez Agencję Żywności i Leków (FDA, Food and Drug Administration) do leczenia idiopatycznego włóknienia płuc i obecnie trwają badania II fazy w przypadku śródmiąższowej choroby płuc w twardzinie układowej płuc (SSc-ILD) [33, 34].

\section{NOWE DROGI HAMOWANIA WLÓKNIENIA W TWARDZINIE UKŁADOWE}

Inne potencjalne możliwości działań terapeutycznych obejmują hamowanie/modulowanie działania profibrotycznych cytokin: Il-6 (inhibitor- Il-6) Il-13 (przeciwciała przeciwko Il-13). Ponadto trwają prace nad inhibitorami międzykomórkowego przekazywania sygnałów włóknienia, takimi jak: monoklonalne przeciwciała anty-CTGF (connective tissue growth factor), endostatin-1-derived peptide, poza tym bada się inhibitory NOX4, a także inhibitory innych ścieżek sygnałowych [35].

Atrakcyjnym celem terapeutycznym byłaby inhibicja czynnika GATA-3, co zmniejszyłoby różnicowanie komórek w linię Th2 i zmniejszyłoby sekrecję IL-13 [36].

\section{INHIBITORY LPA-1 (LIPID \\ LYSOPHOSPHATIDICACID 1)}

Lipidem sygnałowym wykazującym plejotropowe działania w komórkach ssaków jest LPA-1. Poprzez wiązanie z receptorami komórkowymi oddziałuje na wiele szlaków związanych ze wzrostem i przeżyciem komórki, rozważa się jego rolę w rozwoju nowotworów i procesach regeneracji po uszkodzeniu tkanek. Badania na modelach mysich pozbawionych receptora dla LPA-1wykazały zmniejszoną tendencję do rozwoju włóknienia. Mechanizm ten nie jest do końca znany. Na podstawie dowodów przedklinicznych przeprowadzone badanie fazy 2A dało zachęcające wyniki.

\section{STYMULATORY ROZPUSZCZALNEJ CYKLAZY GUANYLOWEJ (SGC)}

Stymulatory rozpuszczalnej cyklazy guanylowej zaaprobowane do leczenia tętniczego nadciśnienia płucnego hamują przekaźnictwo zależne od TGF-beta i mogą hamować włóknienie [33, 37].

\section{TERAPIA Z WYKORZYSTANIEM CZĄSTECZEK ANTAGOMIRS}

Anti-miRs to grupa chemicznie zmodyfikowanych oligonukelotydów, które zapobiegają wiązaniu innych cząsteczek z określonym miejscem w cząsteczce mRNA. Są wykorzystywane do blokowania endogennego mikroRNA (miR) i mogą być zastosowane w celach terapeutycznych. Ich zalety to między innymi możliwość podania dożylnie i długi czas działania. Ta technologia została użyta do oddziaływania na miRs w zwierzęcych modelach wielu chorób. Pierwszy anti-miR zastosowany klinicznie to miravirsen - eksperymentalny lek do leczenia wirusowego zapalenia wątroby typu $\mathrm{C}$. Zastosowanie antagomiR skierowane przeciwko miR21 wykazało skuteczność w włóknieniu płuc [38].

\section{PODSUMOWANIE}

Ze względu na wieloczynnikową patogenezę choroby prowadzone są badania nad cząsteczkami działającymi w różnych mechanizmach i oddziałującymi na różne cele komórkowe. Lepsze poznanie mechanizmów immunologicznych istotnych w rozwoju tej choroby pozwoli na opracowanie nowych strategii terapeutycznych i w przyszłości poprawi skuteczność leczenia. Biorąc pod uwagę różnorodność obrazów klinicznych dalsze poznawanie mechanizmów molekularnych leżących u podstaw tej choroby pozwoli być może w przyszłości na opracowanie bardziej spersonalizowanego leczenia. 